\title{
Manajemen Penguatan Pendidikan Karakter Siswa pada Mata Pelajaran Pendidikan Kewarganegaraan (PKN)
}

\author{
Dalpah Solihah ${ }^{1}$, Iim Wasliman ${ }^{2}$, Ricky Yoseptry ${ }^{3}$ \\ 1,2,3Sekolah Pascasarjana, Universitas Islam Nusantara Bandung, Indonesia \\ E-mail: dalpah.solihah0703@gmail.com,iim-wasliman65@gmail.com,rickyyoseptry01@gmail.com
}

\section{Article Info \\ Article History \\ Received: 2021-12-27 \\ Revised: 2022-01-22 \\ Published: 2022-02-03}

Keywords:

Management;

Strengthening;

Character Education:

Students.

\begin{abstract}
The background of this research is the decline of the Indonesian nation and state today, not only caused by the economic crisis but also by the moral crisis. Education until now has not shown the expected results in accordance with the foundation and objectives of education. The formation of intelligent human beings who are balanced with the values of faith, piety and noble character has not been realized. Moral and moral values among society have begun to fade and are disturbing. UU no. 20 of 2003 concerning the National Education System in article 3, which states: "National education functions to develop capabilities and shape the character and civilization of a dignified nation in the context of the intellectual life of the nation". The purpose of this study was to describe the management of strengthening student character education in civic education subjects at Dharma Kartini Middle School and Darussurur Middle School Plus, Cimahi City. The specific objectives are to find out 1) Planning, 2) organizing, 3) implementing, controlling inhibiting and supporting factors, 6) overcoming obstacles, 7) The impact of strengthening student character education in civic education subjects in junior high schools. This research uses a qualitative approach with a case study method, the subjects in this study are the principal, vice principal of curriculum and teacher of civic education subjects. All stages of management which include planning, organizing, implementing and monitoring have been carried out. This shows that Civics teachers have performed their duties as learning managers quite well, although they are still facing various obstacles and the lack of parental support.
\end{abstract}

\begin{tabular}{l}
\hline Artikel Info \\
\hline Sejarah Artikel \\
Diterima: 2021-12-27 \\
Direvisi: 2022-01-22 \\
Dipublikasi: 2022-02-03
\end{tabular}

Kata kunci:

Manajemen;

Penguatan;

Pendidikan Karakter; Siswa.

\begin{abstract}
Abstrak
Latar belakang penelitian ini adalah terpuruknya bangsa dan negara Indonesia dewasa ini, tidak hanya disebabkan oleh krisis ekonomi melainkan juga oleh krisis akhlak. Pendidikan hingga kini masih belum menunjukan hasil yang diharapkan sesuai dengan landasan dan tujuan Pendidikan. Membentuk manusia yang cerdas yang diimbangi dengan nilai keimanan, ketaqwaan dan berbudi pekerti luhur, belum terwujud. Nilainilai akhlak dan moral dikalangan masyarakat sudah mulai luntur dan meresahkan. UU No. 20 Tahun 2003 tentang Sistem Pendidikan Nasional pada pasal 3, yang menyatakan: "Pendidikan nasional berfungsi mengembangkan kemampuan dan membentuk karakter serta peradaban bangsa yang bermartabat dalam rangka mencerdaskan kehidupan bangsa". Tujuan penelitian ini adalah untuk mendeskripsikan tentang manajemen penguatan pendidikan karakter siswa pada mata pelajaran pendidikan kewarganegaraan di SMP Dharma Kartini dan SMP Plus Darussurur Kota Cimahi. Tujuan khusus untuk mengetahui 1) Perencanaan, 2) pengorganisasian, 3) Pelaksanaan, pengendalian Faktor penghambat dan pendukung, 6) mengatasi hambatan, 7) Dampak dari penguatan pendidikan karakter siswa pada mata pelajaran pendidikan kewarganeraan di SMP. Penelitian ini menggunakan pendekatan kualitatif dengan metode studi kasus, subjek dalam penelitian ini adalah kepala sekolah, waka bidang kurikulum dan Guru mata pelajaran pendidikan kewarganegaraan. Semua tahap manajemen yang mencakup perencanaan, pengorganisasian, pelaksanaan dan pengawasan telah dilaksanakan. Ini menunjukan bahwa guru PKn telah melakukan tugasnya sebagai manajer pembelajaran yang cukup baik, walaupun masih menghadapi berbagai kendala minimnya dukungan orang tua.
\end{abstract}

\section{PENDAHULUAN}

Pendidikan merupakan suatu kebutuhan mutlak untuk mencerdaskan anak bangsa juga untuk membangun moral, kepribadian, mental dan akhlak yang baik guna menjadi tiang pe- nyangga bagi bangsa dan Negara, karakter merupakan salah satu aspek kepribadian manusia yang diyakini dapat merubah, dari yang baik menjadi buruk atau sebaliknya, dari yang buruk menjadi baik, itulah sebabnya pem- 
bangunan karakter menjadi sesuatu yang sangat penting bagi kehidupan manusia itu sendiri baik skala individu maupun skala bangsa.

Pendidikan karakter merupakan pendidikan nilai, pendidikan budi pekerti, pendidikan moral, dan pendidikan watak yang bertujuan mengembangkan kemampuan peserta didik untuk memberikan keputusan baik-buruk, memelihara apa yang baik dan mewujudkan kebaikan itu dalam kehidupan sehari-hari dengan sepenuh hati. Pendidikan karakter merupakan suatu habit, maka pembentukan karakter seseorang itu memerlukan communities of character yang terdiri dari keluarga, sekolah, institusi keagamaan, media, pemerintah dan berbagai pihak yang mempengaruhi nilai-nilai peserta didik, semua communities of character tersebut hendaknya memberikan suatu keteladanan, intervensi, dan pembiasaan yang dilakukan secara konsisten dan penguatan. Pada Kenyataannya Pendidikan akhlak belum berjalan sebagaimana yang diharapkan, hal ini seperti dikemukakan oleh Ahmad Chizam Baihaqy (2020:3) dalam tesis yang berjudul "Implementasi Penguatan Pendidikan Karakter melalui mata pelajaran Pendidikan Agama Islam dan Budi Pekerti" (Studi Multisitus di SMA Negeri 02 Batu dan SMK Negeri 1 Batu) bahwa Gerakan Penguatan Pendidikan Karakter ini menjadi semakin mendesak diprioritaskan kare-na berbagai persoalan yang mengancam keutuha masa depan bangsa seperti maraknya tindakan intoleransi dan kekerasan atas nama agama yang mengancam kebhinekaan dan keutuhan NKRI, munculnya gerakan-gerakan separatis, perilaku kekerasan dalam lingkungan pendidikan dan dimasyarakat, kejahatan seksual, tawuran pelajar, pergaulan bebas dan kecenderungan anak-anak muda pada narkoba. Pelajaran Pendidikan Kewarganeragaan (PKn) menjadi suatu pertanyaan sejauh apa implementasi mata pelajaran tersebut dalam membentuk karakter peserta didik, dalam hal ini peneliti menjadikan SMP Dharma Kartini dan Plus Darussurur Kota Cimahi sebagai objek penelitan peneliti. Alasan pemilihan sekolah tersebut berdasarkan hasil wawancara yang dilakukan kepada wakil kepala sekolah bidang Kurikulum yang menyampaikan bahwa siswa sekolah mengalami permasalahan karakter yaitu penumbuhan kedispilinan patuh pada atur-an sosial, kesadaran akan hak dan kewajiban, nasionalis, menghargai keberagaman, tanggung jawab, berfikir logis, kritis, kreatif, inovatif dan kemandirian pada penerapan Penguatan Pendi-dikan Karakter yang belum terintegrasi dengan dengan baik. Sementara pada
SMP Dharma Kartini wawancara dilakukan pada guru mata pelajaran Pendidikan Kewarganegaraan yang menyampaikan bahwa permasalahan yang terjadi saat ini kurangnya kejujuran siswa, selama pembelajaran daring /belajar dari rumah, hanya beberapa siswa yang mengerjakan dengan jujur dilihat dari bahasa pengerjaan tugasnnya yang mirip dengan bahasa pencarian melalui sistem online yakni google, kurangnya sikap disiplin, kurangnya rasa tanggung jawab dalam me-ngumpulkan tugas yang diberikan oleh guru, siswa menganggap bahwa tugas tersebut bukan prioritasnya.

Pendidikan karakter bertujuan memperkuat identintas dan jati diri peserta didik, jati diri peserta didik ini penting untuk identintas peserta didik pada saat bersosialisasi dengan orang lain, untuk menunjukan siapa dirinya melalui karakter yang ditampakan, pertumbuhan karakter tidak dapat dipisahkan dari proses pendidikan secara keseluruhan. Setiap faktor dalam sekolah memberikan konstribusi dalam pembentukan karakter setiap siswa untuk menyesuaikan pendidikan karakter di sekolah perlu diidentifikasikan karakter, karena tanpa identifikasi karakter akan menjadi sebuah perjalanan panjang tanpa ujung. Pengembangan karakter ini dapat ditemui di mata pelajaran Pendidikan Kewarganegaraan (PKn), dalam pelajaran Pendidikan Kewarganegaraan (PKn) yang diajarkan nilai-nilai karakter yang ditanamkan seperti religius, jujur, toleransi, disiplin, demok-ratis, semangat kebangsaan, cinta tanah air, peduli lingkungan dan tanggung jawab. Sebagai perbandingan dalam penelitian ini, peneliti memilih dua SMP yang berada di Kota Cimahi, secara akreditasi kedua sekolah memiliki perbandingan yang berbeda, dimana SMP Plus Darussurur mendapatkan nilai akreditasi ter-akhir " $A$ ", sementara SMP Dharma Kartini men-dapatkan akreditasi terakhir "B".

\section{METODE PENELITIAN}

Metode penelitian ini yaitu menggunakan pendekatan kualititatif dengan penelitian deskriptif, dapat dikatakan bahwa penelitian deskriptif merupakan penelitian yang berusaha mendeskripsikan suatu gejala, peristiwa yang terjadi pada saat sekarang atau masalah aktual. Teknik pengumpulan data dalam penelitian ini menggunakan teknik pengumpulan data wawancara, observasi dan dokumentasi. Teknik pengolahan data yang digunakan dalam penelitian ini adalah analisis data kualitiatif yang dilakukan secara interaktif dan berlangsung 
secara terus menerus sampai tuntas, sehingga datanya sudah jenuh Teknik analisis data yang digunakan dalam penelitian kualitatif mencakup transkip hasil wawancara, reduksi data, analisis, interpretasi data dan triangulasi, sesuai dengan judul penelitian maka lokasi untuk penelitian adalah SMP Dharma Kartini beralamat lengkap di Jalan Maharmartanegara No.21 Kecamatan Cimahi Selatan Kota Cimahi dan SMP Plus Darussurur yang beralamat di Jalan Nanjung Kampung Panyaweuyan RT/RW 02/13 Kelurahan Utama Kecamatan Cimahi Selatan Kota Cimahi.

\section{HASIL DAN PEMBAHASAN}

Berdasarkan hasil observasi, wawancara dan dokumentasi yang dilakukan di lapangan banyak menemukan berbagai persepsi yang bisa mengarah kepada perencanaan dalam meningkatkan penguatan karakter siswa di dalam suatu mata pelajaran PKn yang sesuai dengan visi, misi dan tujuan mata pelajaran Pkn dalam kurikulum 2013, model pembelajaran yang digunakan menggunakan scientific. Media pembelajaran yang digunakan adalah Lembar kerja peserta didik (LKPD) yang merupakan buku ajar cetak berupa lembar-lembar kertas kerja yang berisi materi, ringkasan dan petunjuk-petunjuk pelaksanaan tugas pembelajaran yang harus dikerjakan oleh siswa. Pembagian tugas dalam proses penguatan pendidikan karakter yang telah terorganisir tugas-tugas tersebut sudah terbagi sebagai tupoksi (tugas pokok dan fungsi) dalam kegiatan Penguatan Pendidikan Karakter, seperti pada rincian tugas kepala sekolah sebagai penentu kebijakan dan pengarah dalam pelaksanaan pendidikan karakter di sekolah selain sebagai pejabat struktural dan administratif di sekolah, kepala sekolah juga berfungsi sebagai supervisor pengawasan dan pembimbingan untuk dinamika kelompok guru dan lainnya. Kepala sekolah juga sebagai pelaku yang menentukan proses berjalannya organisasi dan program kegiatan yang dilaksanakan sekolah termasuk pada kegitan penguatan pendidikan karakter.

Struktur Organisasi penguatan pendidikan karakter di SMP Dharma Kartini tidak ada bentuk fisik tetapi pengorganisasian dilaksanakan secara langsung sesuai dengan struktur organigram sekolah, Guru Pkn SMP Dharma Kartini membentuk kerjasama atau koordinasi dalam menanggani pendidikan karakter terutama dalam proses penilaian, pengawasan dan rencana penanaman pendidikan karakter dengan melibat- kan semua warga sekolah, kepala sekolah dan wakil bidang kurikulum sebagai pengawas dan pengendali, siswa seba-gai output dan pembinaan ekstrakurikuler yang berhubungan de-ngan mata pelajaran PKn. (CL. A1, A2, A3. Dok. 28 September 2021).

Berdasarkan hasil temuan di lapangan guru PKn membuat RPP yang didalamnya terdapat motivasi tentang penguatan pendidikan karakter di kegiatan pendahuluan dalam pembelajaran. Guru bersama dengan siswa melakukan tahap persiapan diawali dengan do'a bersama, lalu mengecek kehadiran dan keadaaan siswa di kelas. Kegiatan inti dalam pembelajaran PKn, guru memasukan atau menanamkan nilai karakter religius, nasionalis, mandiri, integritas, dan gotong royong, pada tahap persiapan pembelajaran guru menginstruksikan ketua kelas untuk memimpin do'a, guru mengecek kehadiran siswa, dan keadaan kelas dari segi kerapihan dan kebersihannya, lalu guru menyampaikan KI/KD. Materi yang akan diajarkan dan sistem penilaian yang akan dilakukan dan nilai-nilai karakter sebagai penilaian sikap. Guru menyampaikan standar kompetensi minimal yang harus dicapai sebagai tolak ukur hasil pencapaian.Rencana pelaksanaan pembelajaran di SMP Dharma Kartini sudah memuat nilai-nilai yang mengarah pada Penguatan pendidikan karakter.

Perencanaan merupakan penyusunan rangkaian kegiatan yang akan dilaksanakan untuk mencapai tujuan, agar setiap langkah dalam kegiatan tersebut dapat terarah dan berjalan secara efektif dan efisien, perencanaan pendidikan adalah pemilihan fakta-fakta dan usaha menghubung-hubungkan antara fakta yang satu dengan fakta yang lain dalam aktivitas pendidikan, kemudian memprediksi keadaan dan perumusan tindakan kependidikan untuk masa yang akan datang yang sekiranya diperlukan untuk mencapai hasil yang dikehendaki dalam pendidikan (Hikmat, 2009:101). Sesuai dengan pengertian para ahli bahwa perencanaan merupakan hal penting yang perlu direncanakan meliputi:

1. Tujuan yang akan dicapai.

2. Kegiatan yang akan dilaksanakan.

3. Prosedur dan metode yang akan dilaksanakan.

4. Penetapan waktu pelaksanaan.

Nilai teologi yang merupakan unsur religius yang mencerminkan keberimanan kepada Tuhan Yang Maha Esa diwujudkan dalam perilaku melaksanakan ajaran agama dan kepercayaan yang dianut, menghargai perbedaa agama, nilai karakter religius ini ditunjukan dalam sikap 
damai, toleransi, menghargai perbedaan agama, percaya diri, mencintai lingkungan dijadikan pula dasar perencanaan pelaksanaan pembelajaran baik di dalam kelas maupun pendidikan di luar kelas, juga nilai Fisiologi penguatan pendidikan karakter menumbuhkan rasa percaya diri, dengan kekuatan dan dukungan yang diberikan oleh pihak sekolah.

\section{SIMPULAN DAN SARAN}

\section{A. Simpulan}

Berdasarkan penelitian yang telah dilakukan, maka dapat disimpulkan Perencanaan pengu-atan pendidikan karakter pada mata pelajaran PKn telah dilakukan untuk mensukseskan pendidikan karakter, perencanaan yang dilakukan sesuai dengan langkahlangkah yang di-sampaikan para ahli manajemen pendidikan karakter dimana kedua sekolah menentukan nilai karakter yang utama dalam mata pelajaran PKn yang sesuai dengan visi, misi, dan tujuan mata pelajaran PKn dalam kurikulum 2013 mencantumkan nilai-nilai yang mengarah pada nilai utama penguatan pendidikan karakter pada mata pelajaran PKn dalam silabus dan RPP. Merencanakan kegiatan pembiasaan penguatan pendidikan karakter yang akan dilaksanakan, menentukan model pembelajaran yang sesuai dengan penguatan pendidikan karakter yang akan diterapkan menentukan bentuk kegiatan penguatan pendidikan karakter. Pengorganisasian penguatan pendidikan karakter pada dasarnya dilaksanakan sesuai dengan tugas pokok dan fungsi (tupoksi) yang tercantum dalam struktur organisasi sekolah namun tidak ada bukti autentik/fisik berupa struktur organisasi penguatan pendidikan karakter, pada tahap pelaksanaan Penguatan Pendidikan Karakter siswa pada mata pelajaran pendidikan kewarganegaraan yang dilaksanakan mengikuti langkah pelaksanaan yang sudah dicantumkan pada perangkat pembelajaran yaitu RPP dan Silabus, juga tahapan pelaksanaan yang dilakukan mengikuti penyampaian para ahli manajemen pendidikan karakter yang mencakup penetapan waktu pelaksanaan, pemberian contoh teladan dan panutan, kegiatan pembiasaan rutin, pelaksanaan penguatan pendidikan karakter telah berjalan dengan baik dan lancar.

Pengawasan yang dilakukan oleh kepala sekolah, waka bidang kurikulum dan guru PKn untuk memantau pelaksanaan Penguatan Pendidikan Karakter, pengawasan dilakukan melalui langkah-langkah yang ada pada teori manajemen, dimana sekolah melakukan penentuan standar dasar bagi pengawasan, melakukan pengukuran pelaksanaan, membandingkan pelaksanaan dengan standar yang ada. Guru menggunakan teknik dan bentuk penilaian sesuai dengan kurikulum 2013. Setiap pihak terkait bisa saling mengawasi satu sama lain, dalam artian mendukung pelaksanaan agar sesuai. Jika ada temuan (kekeliruan) atau hal yang kurang baik, dapat saling menegur atau memberi peringatan untuk ditindaklanjuti, yang menjadi faktor pendukung yakni adanya peran orang tua yang kooperatif dalam mendamping dan mengawasi siswa saat belajar di rumah yang sejalan dengan aturan yang telah dibuat sekolah, dukungan lingkungan/peran serta masyarakat (pemuka agama) dalam menanamkan karakter religius siswa. Sedangkan yang menjadi faktor penghambat yakni orang tua yang terlalu sibuk bekerja sehingga kurangnya pengawasan dan pendampingan siswa saat belajar atau saat berada di lingkungan masyarakat, kurangnya kesadaran para guru dalam memantau atau pengawasan guru terhadap pembelajaran secara daring, sarana dan media yang masih belum sesuai dengan kebutuhan siswa baik dari segi jumlah maupun segi kelayakan, juga banyaknya ancaman yang muncul dari luar sekolah terhadap siswa, untuk mengatasi hambatanhambatan tersebut, upaya yang dilakukan oleh kedua SMP tersebut dengan memaksimalkan fasilitas yang ada dan melibatkan orang tua sebagai sarana untuk memantau kegiatan belajar siswa di luar sekolah, sehingga hambatan tersebut bisa diatasi, manajemen penguatan pendidikan karakter siswa untuk meningkatkan karakter siswa pada SMP menggunakan penyesuaian, dalam hal ini mengutamakan kerjasama, adanya kekeluargaan antar warga sekolah, dukungan orang tua, masyarakat saling membantu, peningkatan kedisiplinan dalam karakter siswa, dari dampak tersebut terbentuknya karakter siswa dilihat dari sudut pandang sebuah implementasi karakter bahwa seseorang dapat dikatakan memiliki pola karakter yang baik berawal dari kedisiplinan dalam membentuk suatu kepribadian sehingga akan muncul lima nilai karakter PPK yakni, Religius, Nasionalis, Mandiri, Gotong Royong, dan Integritas. 


\section{B. Saran}

Berdasarkan temuan selama melaksanakan penelitian, terkait dengan Manajemen Penguatan Pendidikan Karakter pada mata pelajaran Pendidikan kewarganegaraan di SMP Dharma Kartini dan SMP Plus Darussurur Kota Cimahi terdapat rekomendasi sebagai berikut:

1. Kepala sekolah sebagai pemimpin pendidikan yang benar-benar mengoptimalkan manajemen PPK sesuai dengan fungsi dan perannya sebagai kepala sekolah baik melalui akademik maupun non- akademik yang akan berdampak pada karakter siswa.

2. Kepada Guru PKn disarankan untuk memberdayakan komunikasi dan meningkatkan dukungan dalam penguatan pendidikan karakter serta meningkatkan frekuensi, komunikasi dengan para guru dan orang tua saling bertukar pengalaman dalam meningkatkan penguatan pendidikan karakter sehingga dengan adanya komunikasi dapat meningkatkan pendidikan karakter.

\section{DAFTAR RUJUKAN}

Abdul Manab. (2015) Penelitian Pendidikan: Pendekatan Kualitatif. Yogyakarta: Kalimedia.

Albertus, Dodi Koesuma (2010). Pendidikan Karakter Utuh dan Menyeluruh. Yogyakarta. Kanisius.

Ara Hidayat \& Imam Machali. (2012). Pengelolaan Pendidikan. Bandung: Kaukaba.

Arikunto. (2006). Prosedur Penelitian Suatu Pendekatan Praktek. Jakarta: PT. Rineka Cipta.

Creswell, John W. (2003). Qualitative, Quantitative, and Mix Methods Approaches Second Edition. London: Sage Publications.

Dale, Ernest. (1997). Organization, American Management Associations, New York.

Darmadi, Hamid. (2010). Kemampuan Dasar Mengajar. Bandung: Alfabeta.

Djahiri, Ahmad Kosasih. (1995/1996). Dasardasar Umum Metedologi dan Pelajaran Nilai dan Moral PVCT. Purwakarta IKIP
Djumhur dan Moh. Surya. (2008). Bimbingan Dan penyuluhan Konseling di Sekolah. Bandung: Rineka Cipta.

Feriyanto, Andri dan Shyta, Endang Triana. (2015). Pengantar Manajemen (3 in 1). Kebumen: Mediatera.

Griffin, Ricky W. (2004). "Manajemen”. Jakarta : Erlangga.

Hadi, Sutrisno. (1991). Metodelogi Reseach II. Jakarta : Andi Ofset.

Harun, Cut Zahri. (2009). Manajemen Sumber Daya Pendidikan. Yogyakarta: Pena Persada Desktop Publisher.

Hasibuan, Malayu S.P. (2007). Manajemen Sumber Daya Manusia Perusahaan. Bandung: PT. Bumi Aksara.

Hikmat. (2009). Menejemen Pendidikan. Bandung: Pustaka Setia.

Imam Gunawan. (2013). Metode Penelitian Kualitatif Teori dan Prakti. Jakarta: Bumi Aksara.

Karyoto. (2016). Dasar-dasar Manajemen. Yogyakarta: Andi Yogyakarta.

Lincoln, Yvonna S \& Egon G. Guba. (1985). Naturalistic Inquiry. California: Sage.

Makmun, Abin Syamsudin dan Udin Syaefudin Sa'ud. (2006). Perencanaan Pendidikan, Suatu Pendekatan Komprehensif. Bandung: PT. Remaja Rosdakarya.

Mulyasa, Encho. (2004). Kurikulum Berbasis Kompetensi. Bandung: Remaja Rosdakarya Offset.

Najib, M. dkk. (2015). Manajemen Masjid Sekolah Sebagai Laboratorium Pendidikan Karakter Konsep dan Implementasinya. Yogyakarta: Gava Media.

Nasution. S. (2003) Metode Penelitian Kualitatif. Bandung : Tarsito

Nurdin, Syafruddin. (2005). Guru Profesional \& Implementasi Kurikulum. Jakarta: Quantum Teaching.

Rifa'i, Muhammad. (2018) Manajemen Peserta Didik (Pengelolaan Peserta Didik Untuk 
Efektivitas Pembelajaran. Medan: CV. J. Sosial and D. A. N. Humaniora, "Eko Prasetiyo, Widya Puspita.

R. Terry, George. (1993). Prinsip-prinsip Manajemen. Terj. J. Smith, Jakarta: Bumi Aksara.

Rohman, Muhammad dan Sofan Amri. (2012). Manajemen Pendidikan. Jakarta: PT Prestasi Pustakaraya.

Sanusi, Ahmad. (2012). Sistem Nilai. PT Nuansa Cendekia.

Siagian, Sondang P. (2006). Manajemen Sumber Daya Manusia, Cetakan Ketiga belas, Bumi Aksara, Jakarta.

Sudjana, Nana. (2004). Dasar-dasar Proses Belajar Mengajar. Bandung : Sinar Baru Algendindo Offset.

Stake, Robert E. (2005). Case Study Methods in Educational Research: Seeking Sweet Water. In R. M. Jaeger (Ed.) Complementary methods for research in education, 2nd Edition (pp, 401-414). American Educational Research Association: Washington, DC.

Sugiyono. (2014). Metode Penelitian Kualitatif dan Kuantitatif $R \& D$.

E. D. I. Sekolah, "Penguatan Pendidikan Karakter Melalui Kegiatan Ekstrakurikuler Di Sekolah," Sosio Reli. J. Kaji. Pendidik. Umum, vol. 15, no. 1, 2017.

P. Sudibyo, "Manajemen Pendidikan Karakter di Taman Kanak-Kanak BIAS Palagan Yogyakarta," J. Pendidik. Karakter, vol. 03, no. 2, pp. 195-206, 2015.

P. Panoyo, Y. Riyanto, and W. Handayaningrum, "Manajemen Penguatan Pendidikan Karakter Pada Sekolah Menengah Atas," Halaqa Islam. Educ. J., vol. 3, no. 2, p. 111, 2020, doi: 10.21070/halaqa.v3i2.2714.

N. S. Hartati, A. Thahir, and A. Fauzan, "Manajemen Program Penguatan Pendidikan Karakter Melalui Pembelajaran Daring dan Luring di Masa Pandemi Covid 19-New Normal," J. Chem. Inf. Model., vol. 53, no. 9, pp. 1689-1699, 2019.
Suyatno , Aliyah Rasyid Baswedan ( Manajemen Pendidikan, Universitas Ahmad Dahlan Yogyakarta) Selama ini PPK masih berfokus pada guru ( teacher center) maka dengan berfokus pada siswa ( student center ) diharapkan nilai PPK dapat terimp," vol. 2, no. 1, pp. 1-18, 2020.

B. Menapace, "Pendidikan kewarganegaraan sebagai pendidikan karakter," Print and Promo, vol. 56, no. 11, pp. 40-42, 2018.

U. Hubbi, A. Ramdani, and D. Setiadi, "Integrasi Pendidikan Karakter kedalam Pembelajaran Pendidikan Agama Islam dan Pendidikan Kewarganegaraan di Era Milenial," J. Ilmu Sos. dan Pendidian, vol. 4, no. 3, pp. 28-239, 2020.

B. S. Bachri, "Meyakinkan Validitas Data Melalui Triangulasi Pada Penelitian Kualitatif," Teknol. Pendidik., vol. 10, pp. 46-62, 2010.

W. Darmalaksana, "Metode Penelitian Kualitatif Studi Pustaka dan Studi Lapangan," Preprint Digit. Libr. UIN Sunan Gunung Djati Bandung, pp. 1-6, 2020, [Online]. Available: http://digilib.uinsgd.ac.id/32855/1/Metod e Penelitian Kualitatif.pdf.

Baihaqy, Ahmad Chizam. (2020). Implementasi Penguatan Pendidikan Karakter melalui mata pelajaran Pendidikan Agama Islam dan Budi Pekerti (Studi Multisitus di SMA Negeri 02 Batu dan SMK Negeri 1 Batu).

Khamalah, Nur. (2019). Manajemen Pendidikan Karakteri di Madrasah Tsanawiyah 2 Brebes.

Lukluk, Rohmatun I. (2017). Penguatan Pendidikan Karakter Siswa Melalui Manajemen Bimbingan dan Konseling Islam.

Maisaro, Atik. (2018). Manajemen Program Penguatan Pendidikan Karakter Di Sekolah Dasar. 